\title{
Hubungan Lama Menjalani Kemoterapi Dengan Kualitas Hidup Penderita Kanker Payudara Di RSUD Ulin Banjarmasin
}

\author{
Mahmuddin1, Dhian Ririn Lestari2, Ichsan Rizany3 \\ 1,2,3Program Studi Ilmu Keperawatan Fakultas Kedokteran Universitas Lambung Mangkurat \\ Jl. A. Yani KM 36 Banjarbaru, 70714 \\ Email korespondensi : mahmuddiinn@gmail.com
}

DOI: $10.33859 / \mathrm{dksm} . v 10 \mathrm{i} 1.455$

\begin{abstract}
Abstrak
Latar Belakang: Kanker payudara adalah keganasan sel yang menyerang payudara dan merupakan penyebab kematian kedua pada wanita. Frekuensi kemoterapi menimbulkan gangguan pada fungsi dan gejala kanker payudara yang dapat mempengaruhi kualitas hidup. Kualitas hidup merupakan keadaan yang menyatakan kepuasan batin dan kenyamanan hidup seseorang.

Tujuan: Penelitian ini bertujuan untuk mengetahui hubungan lama menjalani kemoterapi dengan kualitas hidup penderita kanker payudara di RSUD Ulin Banjarmasin

Metode: Penelitian ini merupakan penelitian analitik dengan pendekatan cross sectional menggunakan accidental sampling didapatkan 47 responden, penilaian kualitas hidup menggunakan European Organization of Research and Treatment of Cancer (EORTC) BR23. Uji Analisa menggunakan korelasi spearman.

Hasil: Hasil rata-rata lama penderita menjalani kemoterapi sebanyak 4,53 kali dan rata-rata kualitas hidup penderita kanker payudara berada di $65,5 \%$.

Kesimpulan: dari Hasil analisis didapatkan ada hubungan antara lama menjalani kemoterapi dengan kualitas hidup penderita kanker payudara di RSUD Ulin Banjarmasin $(P$ Value $=0,00<0,01)$ dengan arah hubungan positif yakni semakin lama menjalani kemoterapi semakin tinggi nilai kualitas hidup penderita kanker payudara. Kualitas hidup yang paling tinggi dilihat dari function scale adalah sexs enjoyment yakni 72,0 sedangkan dari symptom scale adalah side effect dengan skor 582,6
\end{abstract}

Kata kunci : kanker payudara, kemoterapi, kualitas hidup. 


\title{
Long Relationship Undergo Chemotherapy with Quality of Life of Breast Cancer Patients in Ulin Hospital Banjarmasin
}

\begin{abstract}
Background: Breast cancer is a malignancy cells that attack breast and it is also the second leading cause of death among women. Frequency of chemotherapy may have detrimental function and symptom can make affect for patient's quality of life. Quality of life is defined as condition to which individual reports inner satisfaction and comfort in life.

Aim:The study to identify correlation between duration of chemotherapy and quality of life in patients with breast cancer RSUD Ulin Banjarmasin

Method: This Research use Analitic Method with design was cross sectional and involved 47 patients, all of whom were selected through accidental sampling. European Organization of Research and Treatment of Cancer (EORTC) BR23 was applied to measure patient's quality of life. Anlyssis test using spearman correlation.

Result: The mean of chemotherapy duration among participants was 4.53 times and the mean of QoL of patients with breast cancer was $73.31 \%$.

Conclusion: The analysis revealed a significant correlation between duration of chemotherapy and quality of life in patients with breast cancer in Ulin public hospital of Banjarmasin ( $p$ value = $0.00<0.01)$ with positive direction of association indicating that the longer the duration of make increase the score life quality of patients with breast cancer. The highest quality of life seen from the function scale is sex enjoyment, namely 72.0 while the symptom scale is a side effect with a score of 582.6.
\end{abstract}

Key words: breast cancer, chemotherapy, quality of life 


\section{PENDAHULUAN}

Kanker payudara merupakan sebuah keganasan yang asalnya dari sel dan saluran kelenjar pada payudara serta jaringan yang menunjang payudara, namun kulit dari payudara tidak termasuk. Pada umumnya kanker payudara menyerang wanita yang berusia lebih dari 40 tahun akan tetapi penyakit ini juga bisa menyerang pada wanita usia kurang dari 40 tahun (Purwoastuti, 2008). Berdasarkan data WHO pada tahun 2012 diketahui angka kejadian kanker payudara baru sebesar 43,3\% dan merupakan kanker mematikan kedua pada wanita setelah kanker serviks.

Data penyakit tidak menular (PTM) dari Dinas Kesehatan Provinsi Kalimantan Selatan tahun 2017 menunjukkan kanker payudara di urutan ke 8 dengan 258 penderita. Berdasarkan data kunjungan pasien pada Rumah Sakit Umum Daerah (RSUD) Ulin Banjarmasin, kunjungan pasien kanker dari bulan Januari sampai Maret 2018 sebanyak 937 kunjungan.

Kanker payudara menduduki peringkat pertama, yaitu sebesar $37,9 \%$ atau 356 kunjungan, disusul dengan kanker serviks yang menduduki peringkat kedua sebesar $12,05 \%$ atau 113 kunjungan diurutan ketiga kanker ovarium dengan angka kunjungan 62 atau sebesar $6,6 \%$.

Pengobatan bagi penderita yang telah didiagnosa menderita kanker biasanya dapat diberikan tindakan seperti pembedahan, terapi radiasi, bioterapi, terapi fotodinamik, transplantasi sum-sum tulang dan sel batang, terapi hormon, terapi komplementer dan kemoterapi (Rasjidi, 2009). Kemoterapi terkadang menjadi pilihan pertama dalam penanganan kanker (Rasjidi, 2009). Penggunaan obat kemoterapi bertujuan untuk menangkal dan memperlambat duplikasi selsel kanker serta mencegah penyebaran. Kemoterapi memiliki efek toksik kepada sel yang normal terlebih pada jaringan- jaringan dengan pertumbuhan sel yang cepat (Aziz, 2010). Pada umumnya proses kemoterapi berlangsung selama enam bulan secara keseluruhan dengan beberapa seri pengobatan sekali sebulan, namun pemberian kemoterapi juga bisa bervariasi lamanya. Biasanya 
regimen kemoterapi berlangsung antara 3 sampai 6 bulan (Pamungkas, 2011). Namun, pengobatan kanker dengan kemoterapi bukan berarti tidak menimbulkan efek. Lama menjalani kemoterapi mampu menghasilkan berbagai macam efek yang bisa mempengaruhi kualitas hidup penderita kanker.(Wilensky, 2008)

Kualitas hidup adalah sebuah keadaan yang dapat diartikan sebagai kepuasan batin serta kenyamanan hidup sesorang. Kualitas hidup dapat ditentukan melalui delapan aspek kehidupan, yakni cinta, karier, pendidikan, keturunan, ketenaran, kesehatan, keuangan serta pembimbing (Perwitasari, 2009). Salah satu upaya untuk meningkatkan kualitas hidup penderita kanker adalah dengan mencegah gejala fungsional, gejala fisik serta gejala psikologis yang dirasakan oleh penderita , sehingga kualitas hidup penderita kanker perlu dimengerti oleh keluarga penderita maupun tenaga kesehatan (Perwitasari, 2009).

Berdasarkan hasil studi pendahuluan yang dilakukan pada tanggal 2-8 Mei 2018 di RSUD Ulin Banjarmasin dengan cara melakukan wawancara sederhana terhadap 11 penderita kanker payudara sebanyak 4 orang $(36,4 \%)$ penderita mengatakan fungsi tubuh mereka mengalami perubahan setelah melakukan kemoterapi hal ini terkait dengan kelelahan dan penurunan nafsu makan yang disertai mual muntah sebagai efek samping kemoterapi, dalam hal psikologis ada 6 orang $(54,5 \%)$ penderita yang mengatakan takut dan cemas dalam menjalankan kemoterapi. Berdasarkan fenomena diatas peneliti ingin mengetahui Hubungan lama menjalani kemoterapi dengan kualitas hidup pasien kanker payudara di RSUD Ulin Banjarmasin.

\section{METODE}

Penelitian ini merupakan penelitian analitik bertujuan mengetahui hubungan lama menjalani kemoterapi dengan kualitas hidup penderita kanker payudara di RSUD Ulin Banjarmasin yang dialakukan dari 13 agustus s/d 13 september 2018 dengan pendekatan cross sectional dan jumlah sampel sebanyak 47 orang dengan tekhnik accidental sampling kualitas hidup diukur menggunakan European 
Organization of Research and Treatment of

Cancer (EORTC) BR23 dengan 23 pertanyaan

yang diberikan kepada responden sebelum

pelaksanaan kemoterapi dan kuesioner telah

dilakukan uji validitas dan uji realibitas

sebelumnya dan berdasarkan uji analisis 23

pertanyaan dinyatakan valid dan realibel, sedangkan lama menjalani di lihat dari frekuensi kemoterapi yang tertera di rekam medis responden, uji analisa digunakan korelasi spearman. Penelitian ini menggunakan etika penelitian berupa anonim, kerahasian, berbuat baik serta tidak ada unsur paksaan bagi penderita kanker payudara untuk menjadi subjek pada penelitian ini dan penelitian ini sudah dinyatakan layak etik oleh komisi etik penelitian kesehatan fakultas kedokteran universitas lambung mangkurat dengan nomor 811/ KEPK - FK UNLAM / EC/ VII/ 2018

\section{HASIL}

\section{Karakteristik Responden}

Tabel 1. Karakteristik responden

\begin{tabular}{|c|c|c|}
\hline $\begin{array}{c}\text { Karakteristik } \\
\text { Responden }\end{array}$ & $\begin{array}{l}\text { Frekuensi } \\
\text { (n) }\end{array}$ & $\begin{array}{c}\text { Persentase } \\
(\%)\end{array}$ \\
\hline \multicolumn{3}{|l|}{ UMUR } \\
\hline$\leq 25$ Tahun & 0 & 0 \\
\hline $26-35$ Tahun & 3 & 6,4 \\
\hline $36-45$ Tahun & 11 & 23,4 \\
\hline 46- 55 Tahun & 25 & 53,2 \\
\hline $56-65$ Tahun & 7 & 14,9 \\
\hline$>65$ Tahun & 1 & 2,1 \\
\hline \multicolumn{3}{|l|}{ PEKERJAAN } \\
\hline IRT & 32 & 68,1 \\
\hline PNS/ Polri & 7 & 14,9 \\
\hline Pedagang & 3 & 6,4 \\
\hline Swasta & 0 & 0 \\
\hline Buruh & 1 & 2,1 \\
\hline Lainnya & 4 & 8,6 \\
\hline \multicolumn{3}{|l|}{ STADIUM } \\
\hline Stadium 3 & 37 & 78,7 \\
\hline Stadium 4 & 10 & 21,3 \\
\hline \multicolumn{3}{|c|}{ PENDIDIKAN TERAKHIR } \\
\hline Tidak Lulus SD & 3 & 6 \\
\hline SD/ Sederajat & 17 & 36,2 \\
\hline SMP/ Sederajat & 10 & 21,3 \\
\hline SMA/ Sederajat & 9 & 19,1 \\
\hline Diploma & 1 & 2,1 \\
\hline Sarjana & 7 & 14,9 \\
\hline \multicolumn{3}{|l|}{ PENGHASILAN } \\
\hline < Rp. 2. 454.000 & 21 & 44,7 \\
\hline$\geq$ Rp. 2.454 .000 & 26 & 55,3 \\
\hline \multicolumn{3}{|c|}{ STATUS PERNIKAHAN } \\
\hline Belum Menikah & 0 & 0 \\
\hline Menikah & 39 & 83 \\
\hline Cerai Mati & 6 & 12,8 \\
\hline Cerai Hidup & 2 & 4,3 \\
\hline Total & 47 & 100 \\
\hline
\end{tabular}

Tabel 1 menunjukkan hasil penelitian yang dilakukan dari 47 responden didapatkan karakteristik responden yaitu 25 orang $(53,2 \%)$ mempunyai rentang umur $46-57$ tahun, 32 orang $(68,1 \%)$ merupakan ibu rumah tangga, 37 orang $(78,7 \%)$ berada pada stadium 3,17 orang $(36,2 \%)$ pendidikan terakhirnya 
adalah SD/ sederajat, 26 orang $(55,3 \%)$ mempunyai penghasilan lebih dari Rp. 2. 454. 000 serta responden yang menikah sebanyak 39 orang $(83 \%)$.

Data penelitian menunjukkan bahwa dari 47 responden ketahui bahwa rentang usia 46 55 tahun sebanyak 25 orang (52,3\%), kemudian rentang usia 36 - 45 tahun berada di urutan kedua sebanyak 11 orang $(23,4 \%)$ sedangkan usia dengan rentang 56 sampai 65 tahun berjumlah 7 orang $(14,9 \%)$ berada di urutan berikutnya. Hal ini pun sesuai dengan penelitian Karima (20013) di Jakarta dimana rentang usia responden yang dominan adalah 35 - 54 tahun dan pada rentang ini lebih berisiko terkena kanker payudara dibanding usia < 35 Tahun. Jika dulu penderita kanker payudara rata-rata berada di usia 50 tahun ke atas, akan tetapi pada masa sekarang kebanyakan penderita kanker payudara berada direntang usia 35 - 50 tahun, pergeseran ini dikarenakan salah pola makan, gaya hidup yang tak sehat serta malas berolahraga (Savitri, 2015).
Data pendidikan terakhir yang diselesaikan responden ditemukan bahwa 17 orang $(36,2 \%)$ adalah $\mathrm{SD} /$ sederajat dan yang tidak lulus SD/ sederajat sebesar 6\% (3 orang) sedangkan sebanyak 10 orang $(21,3 \%)$ adalah lulusan SMP/ sederajat. Hasil yang sama didapatkan pada karakteristik responden penelitian penelitian di Jakarta tahun 2013(7) dimana penderita kanker yang hanya lulus SD sebesar $22,7 \%$ (27 orang), tamat SMP sebesar $16,8 \%$ (20 orang) dan yang tidak lulus SD sebanyak 7 orang $(5,9 \%)$. Pada stadium awal kanker yang kebanyakan menyerang pada wanita ini memiliki tanda dan gejala, akan tetapi sering kali tidak dihiraukan karena kurangnya faktor pengetahuan terhadap tanda gejala tersebut sehingga ketika kondisi fisik sudah mulai menurun dan berada pada stadium lanjut barulah memeriksakan diri ke pelayanan kesehatan (Ariani, 2015).

Dilihat dari karakteristik responden berdasarkan stadium kanker payudara yang terbesar adalah stadium 3 atau stadium lanjut lokal yakni sebesar $78,7 \%$ (37 orang). Penelitian Liana (2012) di Pekanbaru juga 
menunjukkan hal yang sama yakni didapatkan bahwa lebih dari separuh responden berada pada stadium lanjut lokal yakni sebanyak 47 orang $(53,7 \%)$. Hampir 70 persen pasien kanker pada payudara datang ke fasilitas kesehatan ketika berada pada stadium lanjut. Hanya memerlukan waktu hampir setahun, kanker ini sudah dapat berkembang dari stadium awal ke stadium lanjut sehingga kanker jenis ini merupaka kanker dengan jenis yang memiliki perkembangan sangat cepat (Savitri, 2015).

\section{Lama Menjalani Kemoterapi}

Tabel 2. Lama Menjalani Kemoterapi

\begin{tabular}{ccccc}
\hline Variabel & Mean & SD & MIN & MAX \\
\hline $\begin{array}{c}\text { Lama } \\
\text { Menjalani }\end{array}$ & 4,53 & 2,27 & 2 & 9 \\
kemoterapi & & & & \\
\hline
\end{tabular}

Berdasarkan tabel 2 di ketahui bahwa frekuensi lama menjalani kemoterapi adalah 4,53 kali dengan frekuensi yang tertinggi sebanyak 9 kali dan frekuensi yang paling sedikit sebanyak 2 kali Jarak antar frekuensi kemoterapi adalah 21 hari, sehingga dapat disimpulkan bahwa responden rata - rata sudah menjalani kemoterapi selama kurang lebih 3 bulan, hasil penelitian di Semarang pada tahun 2016(15) juga menunjukkan hal yang sama yakni bahwa rata-rata penderita sudah menjalani kemoterapi lebih $\geq 3$ bulan sebesar $66,7 \%$ (26 orang).

Karakteristik responden yang didominasi oleh tingkat pendidikan dasar yakni 17 orang $(36,2 \%)$ adalah $\mathrm{SD} /$ sederajat dan yang tidak lulus SD/ sederajat sebesar 6\% (3 orang) sedangkan sebanyak 10 orang $(21,3 \%)$ adalah lulusan SMP/ sederajat, sehingga peneliti berasumsi bahwa penderita lambat mendeteksi dirinya terkena kanker payudara dan cenderung mengabaikannya karena tingkat kesadaran dan informasi penderita mengenai kanker payudara kurang. Akibatnya deteksi kanker payudara sudah berada di stadium lanjut, hal ini dapat dilihat berdasarkan karakteristik responden yang kebanyakan berada di stadium lanjut yakni stadium 3 sebanyak 37 orang $(78,7 \%)$ dan stadium 4 sebanyak 10 orang $(21,3 \%)$, maka peneliti juga berasumsi bahwa keterlambatan responden mengenali tanda - tanda adanya kanker pada payudara berakibat terhadap keterlambatan pendiagnosaan kanker payudara. Ketika 
kanker sudah terdeteksi berada pada stadium lanjut sehingga pengobatan yang dilakukan pun semakin lama dan semakin sulit.

\section{Kualitas Hidup Penderita Kanker Payudara}

Tabel 3. Kualitas Hidup

\begin{tabular}{lcccc}
\hline \multicolumn{1}{c}{ Variabel } & Mean & SD & Min & Max \\
\hline$\quad$ Function scale & & & & \\
Body Image & 60,6 & 16,3 & 33 & 100 \\
Sexual Function & 70,6 & 28,7 & 0 & 100 \\
Sexual Enjoyment & 72,0 & 26,4 & 0 & 100 \\
Future Persfective & 61,9 & 21,5 & 0 & 100 \\
$\quad$ Symptom scale & & & & \\
Side Effect & 582,6 & 106,0 & 266 & 866 \\
Breast Symptom & 76,7 & 18,8 & 33 & 100 \\
Arm Symptom & 73,1 & 33,0 & 33 & 100 \\
Hair Loss & 48,5 & 24,9 & 0 & 100 \\
\hline & & & &
\end{tabular}

Dari tabel di atas dapat dilihat bahwa rerata kualitas hidup penderita kanker payudara yang paling besar dilihat dari function scale adalah sexual enjoyment sebesar 72,00 sedangkan dilihat dari symptom scale adalah side effect sebesar 582,66.

Peneliti berasumsi bahwa dukungan pasangan dalam menjalani pengobatan kemoterapi juga berpengaruh terhadap kualitas hidup penderita, hal ini bisa terlihat melalui karakteristik responden pada penelitian ini dengan status pernikahan menikah sebesar 83\% (39 orang). Status pernikahan merupakan salah satu faktor dari beberapa faktor yang mampu mempengaruhi kuaIitas hidup indvidu.
Seseorang yang tidak mempunyai pasangan baik dikarenakan tidak menikah atau bercerai maupun individu yang pasangannya meninggal memiliki kualitas hidup yang lebih rendah daripada individu atau seseorang yang memiliki pasangan (Amalia, 2002).

Dari pernyatan responden diketahui bahwa $42,55 \%$ (20 orang) tertarik dengan hubungan seksual, bahkan sebanyak 19 orang (40,42\%) aktif melakukan aktivitas seksual dan sebanyak 18 orang $(38,29 \%)$ masih sangat menikmati aktivitas tersebut. Penelitian yang dilakukan (Demerci, 2011) di Turki juga menunjukkan hasil yang sama yakni penderita kanker payudara masih menikmati aktivitas seksual. Kualitas hidup bisa didefinisikan sebagai sebuah tingkat dimana individu mampu merasakan kepuasan didalam kehidupan yang dijalaninya, oleh karena itu individu tersebut harus menjaga kesehatan fisik, pikiran serta jiwa untuk mencapai tingkat kepuasan tersebut. Hingga pada akhirnnya individu tersebut mampu melaksanakan berbagai aktivitas tanpa adanya gangguan (Ventegodt, 2011) 
Hubungan Lama Menjalani Kemoterapi Dengan Kualitas Hidup Penderita Kanker Payudara di RSUD Ulin Banjarmasin

Tabel 4. Hubungan lama menjalani kemoterapi dengan kualitas hidup

\begin{tabular}{lcc}
\hline \multicolumn{1}{c}{ Variabel } & p Value & R \\
\cline { 1 - 1 } $\begin{array}{l}\text { Lama Menjalani } \\
\text { kemoterapi }\end{array}$ & 0,000 & 0,574 \\
\cline { 1 - 1 } $\begin{array}{l}\text { Kulitas hidup } \\
\text { penderita kanker }\end{array}$ & & \\
Payudara & & \\
\hline
\end{tabular}

Hasil analisis data pada tabel 4 tentang hubungan lama menjalani kemoterapi dengan kualitas hidup penderita kanker payudara di RSUD Ulin Banjarmasin, di dapatkan nilai signifikan lama menjalani kemoterapi dengan kualitas hidup penderita kanker payudara di RSUD Ulin Banjarmasin adalah $(p=0,000)$. Hasil analisa didapatkan $p$ value $<a(0,000<$ 0,01), yang mempunyai arti ada hubungan yang signifikan antara lama menjalani kemoterapi dengan kualitas hidup penderita kanker payudara dengan koefisien korelasi (r) 0, 574 dengan arah hubungan positif dan kekuatan korelasi sedang, yang artinya semakin lama menjalani kemoterapi maka kualitas hidup penderita kanker payudara semakin baik. Hasil tersebut sejalan dengan hasil penelitian Wahyuni (2015) di Tenggarong yakni hasil analisa data dalam penelitian ini diperoleh nilai $\mathrm{p}=0,000<0,05$ sehingga ada hubungan yang bermakna antara frekuensi kemoterapi dengan kualitas hidup perempuan dengan kanker payudara yang menjalani kemoterapi. Berdasarkan hasil analisa menggunakan Korelasi Spearman Rank terdapat nilai bermakna $\mathrm{r}=0,814$ yang memiliki korelasi positif yang berarti semakin sering frekuensi kemoterapi maka semakin baik nilai kuaIitas hidup perempuan dengan kanker payudara yang menjaIani kemoterapi dan memiliki korelasi sangat kuat.

Kemoterapi merupakan suatu penatalaksanaan kanker sistemik yang bertujuan menyerang sel kanker melalui pemberian obat, berbeda dengan terapi lainya yang bersifat lokal seperti pembedahan dan radiasi, terapi ini mampu menjangkau sel kanker yang telah bermetastase ke daerah lainya (Rasjidi, 2009). Kemoterapi menimbulkan efek yang jelas kepada fisik pasien, setiap pasien memiliki variasi yang beda dalam respon terhadap obat kemoterapi, efek fisik yang tidak diberikan penanganan yang baik dapat mempengaruhi kualitas hidup 
pasien, efek samping kemoterapi cukup beragam salah satunya adalah perubahan rasa dan nyeri (Ambarwati, 2014). Berdasarkan hasil penelitian didapatkan rata-rata dari symptom scale pada item breast symptom 76,77 dan juga diketahui dari kuesioner yang dibagikan ke responden terdapat 23 responden $(48,93 \%)$ tidak merasakan nyeri pada bagian payudara yang terkena kanker dan sebanyak 17 orang $(36,17 \%)$ masih merasakan tapi hanya sedikit, dari item arm symptom diketahui rataratanya sebesar 73,06 dan dari pernyataan responden diketahui bahwa sebanyak 1 orang $(2,1 \%)$ tidak merasakan nyeri dibahunya, 10 orang $(21,3 \%)$ hanya sedikit merasakan nyeri dibahunya dan sebanyak 23 orang $(48,9 \%)$ hanya kadang-kadang saja merasakan nyeri dibahunya. Sehingga peneliti berasumsi bahwa efek samping dari kemoterapi tidak di rasakan oleh sebagian penderita kanker payudara yang menjalani kemoterapi.

Berdasarkan data symptom scale pada item side effect hampir semua responden mengalami kerontokan rambut yakni sebesar 38,29 (18 orang) sangat sering mengalami kerontokan rambut, sebesar 42,55\% (20 orang) cukup sering mengalami kerontokan rambut dan sebanyak 9 orang $(19,11 \%)$ tidak terlalu sering mengalami kerontokan rambut, hal ini tidak lantas membuat semua penderita merasa kecewa, hal tersebut terlihat dari rata-rata item hair loss yakni sebesar 51,15 yang didapat dari pernyataan responden yang menunjukkan bahwa 5 orang $(10,63 \%)$ sama sekali tidak merasa kecewa dengan rontoknya rambut mereka dan sebanyak 14 orang (29,78\%) mengatakan hanya sedikit kecewa dengan rontok rambut mereka dan hanya 2 orang $(4,25 \%)$ saja yang merasa sangat kecewa dengan rontok nya rambut mereka. Peneliti berasumsi bahwa walaupun rambut merupakan mahkota bagi perempuan tapi penderita memandang rontoknya rambut tersebut tidak mempengaruhi penampilan mereka dan mengakibatkan sebagian besar penderita memiliki perasaan positif akan rontok nya rambut tersebut dan merasa tidak kecewa dengan keadaaan tersebut. Body image dan apprearance diartikan sebagai suatu keadaan dimana seseorang menilai 
penampilan dan keadaan tubuhnya sendiri.

Body image dan apprearance merupakan bagian dari dimensi kesejahteraan dimana dimensi kesejahteraan meliputi perasaan positif, perasaan negatif, self-estem dan berfikir, belajar, memori, konsentrasi serta body image dan apprearance (Purwoastuti, 2008).

Pada penelitian ini peneliti berasumsi bahwa semakin sering pasiem menjalani kemoterapi semakin tinggi nilai skor kualitas hidup penderita berupa hal-hal yang mengganggu fisik yang disebabkan oleh banyaknya efek samping dari kemoterapi seperti sakit kepala, badan merasa tidak enak, bibir kering, dan sebagainya. Hal ini dapat dilihat melalui rerata item side effect didapatkan angka 582,66 hal ini dapat ditunjukkan dengan penderita yang tidak pernah merasa tidak enak badan sebanyak 14 orang $(29,78 \%)$ dan sebanyak 21 orang $(44,68 \%)$ hanya sedikit merasakan tidak enak badan dan $29,78 \%$ (14 orang) tidak pernah merasa sakit kepala serta sebanyak 20 orang $(42,55 \%)$ hanya sedikit merasa sakit kepala.
Kesehatan fisik merupakan salah satu domain dari kualitas hidup yang mampu mempengaruhi kualitas hidup yang terdiri dari ketergantungan pada obat-obatan dan bantuan medis, aktivitas sehari-hari, mobilitas, energi dan kelelahan, tidur dan istirahat, sakit dan ketidaknyamanan serta kapasitas kerja (Purwoastuti, 2008).

\section{Kesimpulan}

Hasil rata-rata lama penderita menjalani kemoterapi sebanyak 4,53 kali dan rata-rata kualitas hidup penderita kanker payudara berada di $65,5 \%$. Hasil analisis didapatkan ada hubungan antara lama menjalani kemoterapi dengan kualitas hidup penderita kanker payudara di RSUD Ulin Banjarmasin $(P$ Value $=0,00<0,01)$ dengan arah hubungan positif yakni semakin lama menjalani kemoterapi semakin tinggi nilai kualitas hidup penderita kanker payudara. Disarankan kepada rumah sakit untuk melakukan perawatan paliatif lebih intensif kepada penderita kanker. 


\section{Daftar Pustaka}

Purwoastuti, E. (2008). Kanker Payudara. Yogyakarta : Kanisius.

Rasjidi, Imam. 2009 : Deteksi Dini \& Pencegahan Kanker pada Wanita. Jakarta : Sagung Seto.

Aziz, A. 2010. Kemoterapi : Buku Panduan Pasien, PT. Dian Rakyat, Jakarta.

Pamungkas, 2011. Deteksi Dini Kanker Payudara. Kenali Sebab-sebab dan Cara Antisipasinya. Yogyakarta : Buku Biru.

Wilensky. 2008. Kanker Payudara Diagnosis dan Solusinya. Jakarta : Prestasi Pustaka Karya.

Perwitasari, D, A (2009). Pengukuran Kualitas Hidup Pasien Kanker Sebelum dan Sesudah Kemoterapi dengan Eortc QLQ-C3o RSUD Sardjito Yogyakarta. Majalah Farmasi Indonesia 20 (2).

Karima, Qoulan Ulya, 2013. Faktor - Faktor Yang Berhubungan Dengan Kejadian Kanker Payudara Wanita Di RSUPN Dr. Cipto Mangunkusumo Jakarta Tahun 2013. Jakarta. FKM UI

Savitri, Astrid. 2015. Kupas Tuntas Kanker Payudara, Leher Rahim dan Rahim. Yogyakarta. Pustaka Baru Press

Ariani, Sofi. 2015. Stop Kanker. Yogyakarta. Istana Media

Amalia (2002). Mengobati Kanker Serviks dan 33 Jenis Kanker Lainnya. Jogyakarta : Landscape.

Ventegodt, A.J. 2003. Quality of Life Tuberculosis Theory 1 . The IdolTheory of Life in Tuberculosis Concept.
Wahyuni, T. 2015. Hubungan antara Frekuensi Kemoterapi dengan Kualitas Hidup Perempuan dengan Kanker Payudara yang menjalani kemoterapi di Ruang Kemoterapi RSUD A. M. Parikesit Tenggarong. Jurnal Ilmu Kesehatan. Vol 3 No. 2

Ambarwati, dkk (2014). Efek Samping Kemoterapi secara Fisik Pasien Penderita Kanker Serviks. Jurnal Keperawatan. Vol II

Liana, Laella Kinghua, Dkk. 2012. Karakteristik Pasien Kanker Payudara Dan Penanganannya Di Rsud Arifin Achmad Pekanbaru Periode Januari 2010- Desember 2012. Bandung. Fakultas Kedokteran Universitas Kristen Maranatha

Setiawati, Y. 2016. Hubungan Lama Kemoterapi dengan Kualitas Hidup Pasien Kanker Payudara yang Menjalani Kemoterapi di RSUD Tugurejo Semarang. Stikes Ngudi Waluyo

Demerci, Senem, et all. 2013. Validation of the Turkish Versions of EORTC QLQC30 and BR23 Modules in Breast Cancer Patients. Asian Pacific Journal of Cancer Prevention, Vol 12 